\title{
道路ネットワーク上の内在リスク分析を 踏まえた行政BCP策定に関する研究
}

\author{
坂田 朗夫 1 - 伊藤 則夫 2 - 川本 篤志 $3 \cdot$ 白木 渡 4 \\ 1正会員 豊能町役場 建設環境部建設課（广563-0292大阪府豊能郡豊能町余野414-1） \\ E-mail:kensetsu@town.toyono.osaka.jp \\ 2正会員 (有)シー・エー・イー代表取締役（†680-8064 鳥取市国府町分上2-210） \\ E-mail:itou@cae.jp \\ 3正会員 株荒谷建設コンサルタント コンサルタント第2部（テ730-0833広島市中区江波本町4-22） \\ E-mail:atsushi.kawamoto@aratani.co.jp \\ 4正会員 香川大学教授 危機管理研究センター（テ761-0396高松市林町2217-20） \\ E-mail:shiraki@eng.kagawa-u.ac.jp
}

\begin{abstract}
東日本大震災のような大規模広域災害を想定した場合，従来の防災計画に基づいた対応では十分 とはいえない。今回の地震被害を受けて中央防災会議の中間報告では，起こりうる最大規模の被害 を想定した対応を求めており，各自治体は少なくとも地域全体の業務継続計画（BCP）を策定し，災 害発生後の対応に主眼をおいた危機管理対策が求められる.

本研究においては, 中山間地域の被災者の救助・支援活動に不可欠な山間部の道路ネットワーク に着目し，地方行政の BCP 策定の観点から道路ネットワーク上の内在リスクを評価することとし， 特に自然斜面・切土斜面に着目し，斜面の崩壊に伴う道路閉塞のリスク分析を行い，行政 BCP のあ るべき方向性について検討する.
\end{abstract}

Key Words : risk anlysis, road network, slope failure,neural network, local government, business continuity plan

\section{1. まえがき}

わが国では，2004年 10 月 23 日に発生した新潟県中越 地震を機に，民間企業は社会的責務の立場から業務継続 計画 ${ }^{1)}$ (Business Continuity Plan : 以下，BCP と略する）を 策定し，危機管理能力の向上を目指した努力を払ってき た.これを受けて，総務省内閣府から全国の行政機関に 対しても BCP 策定を急ぐように指示が出された. しか し，行政機関が災害時に対応すべき危機管理対策は多様 で広範囲にわたり，またアクションプランでもある BCP は多様なリスクに対応したものとする必要がある ため，策定作業は容易でなく $\mathrm{BCP}$ の普及は進んでいな いのが現状である.

全国の都道府県と市区町村を対象として, 内閣府によ り 2009 年 11 月に実施された BCP (地震編) の策定状況 調査結果 ${ }^{2}$ によれば，BCP を策定済と回答した都道府 県は 10 団体 (21\%)，市区町村では99団体（5.5\%）と 低い水準にある.このように，大地震への対応の夕に限 定しても既に遅れている状況である，筆者らは，このよ うな状況を鑑みて, 中小の地方行政の $\mathrm{BCP}$ 策定の普
及・推進を目的として, 昨年中小企業 BCP ステップア ップ・ガイド 3)を基に「地方公共団体における業務継 続計画策定ガイド」案 ${ }^{4}$ を作成した.

しかし，2011 年 3 月 11 日に発生した東日本大震災に より，被害が大規模かつ広域に及ぶ場合にはこれまでに 策定された BCP では対応しきれない多くの問題を含ん でいることが明らかになった。

第 1 に，庁舎が津波で流出し多くの職員が被災すると いう被害を受けた沿岸の市町村では活動の拠点ばかりか 人的資源も失われ，救助・支援活動はもちろん被災状況 の把握すら困難な状況に陥った. このような想定外の事 態の発生が，その後の復旧・復興対応に大きな影響を及 ぼすことになる.

第 2 に，道路・鉄道・港湾・空港等交通インフラの壊 滅，燃油の不足などによる物流の機能不全があり，その ため救助・支援活動の遅れ, 被災者の孤立状態の長期化 をもたらした。この事態も BCP の実行性という観点か らすると重要な阻害要因である.

東日本大震災を教訓にして，想定以上の規模の災害に 対して, BCP が機能するのか, どのように対処すべき 
かについて，多くの企業が BCP の見直しを開始してい る. 行政機関においても，上記の第 1 の課題に対して代 替拠点の確保などの八ード的な対策に加えて，周辺地域 の行政機関との連携による BCP の策定などソフト的な 対応も考慮した，従来の枠組みを超えた災害時の広域連 携対応が求められる. また，第 2 の課題についても物資 の効率的な備蓄，あるいは輸送経路の多重化など考慮す べき問題は多岐にわたる.

災害時における行政機関の間の広域連携を考える場合, 被災者の救助・支援を行う上で不可欠な道路ネットワー クが果たす役割は非常に大きい，道路ネットワークは， 緊急対応から災害後の復旧・復興の段階に至るすべての フェーズにおいて，ヒトやモノの移動手段として活用さ れ続けなければならない。しかし，中山間地の道路ネッ トワークを考えた場合，一般に咒長性が低く，土砂災害 等による道路の一部の不通が集落の孤立化につながる恐 れがある．このような脆弱な状況を考えれば，道路の閉 塞に際して迅速な啓開を図るための準備，また集落の孤 立化を防ぐための準備が必要となる，そのためには，道 路ネットワークに内在するリスクや脆弱性を把握・評価 するとともに，孤立化する可能性がある集落について， その危険性を軽減するための対策の検討が求められる.

本研究では, 山間部の道路ネットワークに着目して, 地方行政の $\mathrm{BCP}$ 策定の観点からその内在リスク，特に自 然斜面・切土斜面に着目し，斜面の崩壊に伴う道路閉塞 のリスク分析を行い，地方行政の BCP のあるべき方向性 について検討する.

\section{2. 道路ネットワークの内在リスク分析}

近年，日本列島は異常気象や地震の活動期に突入した

表-1 説明変数

\begin{tabular}{|c|c|c|c|}
\hline № & \multicolumn{2}{|c|}{ データ項目 } & 説 \\
\hline 1 & \multicolumn{2}{|c|}{ 斜面の種類 } & 自然斜面, 人工斜面 \\
\hline 2 & \multicolumn{2}{|c|}{ 斜面の向き } & 北、北東等 8 区分 \\
\hline 3 & \multirow{2}{*}{ 斜面型 } & 横断方向 & 尾根部, 谷部 等 \\
\hline 4 & & 縦断方向 & 上昇型, 下降型 等 \\
\hline 5 & \multirow{2}{*}{$\begin{array}{l}\text { 斜面の } \\
\text { 上端 }\end{array}$} & 状態 & 尾根, 台地 等 \\
\hline 6 & & 利用状況 & 水路又は沢, 道路 等 \\
\hline 7 & \multirow{2}{*}{$\begin{array}{l}\text { 斜面の } \\
\text { 下端 }\end{array}$} & 状態 & 平地, 上昇直線型 等 \\
\hline 8 & & 傾斜角 & 傾斜角（度） \\
\hline 9 & \multicolumn{2}{|c|}{ 斜面の平均傾斜角 } & (度) \\
\hline 10 & \multicolumn{2}{|c|}{ 斜面高 } & (m) \\
\hline 11 & \multirow{2}{*}{ 地被物 } & 種類 & 裸地, 草地 等 \\
\hline 12 & & 密度 & 疎，中, 密 \\
\hline 13 & \multicolumn{2}{|c|}{ 過去の崩壊の有無 } & 同一箇所, 付近の合計回数 \\
\hline
\end{tabular}

影響もあり，災害規模の巨大化、被害の広域化の傾向が 見られる，道路ネットワークは日本列島に網の目のよう に張り巡らされており，一度災害が発生すれば被害が甚 大になることが懸念されている，特に，山間部の道路ネ ットワークは盛土，自然斜面・切土斜面，トンネル及び 橋梁より構成され，それぞれにリスクが存在するため, リスクの発生により複合的な機能障害が発生する.

本研究では, 中山間地域の道路で最も多く存在する自 然斜面・切土斜面に着目し，斜面崩壊に起因する道路不 通のリスクを検討する.

\section{（1）急傾斜地崩壊データの整理}

建設省河川局では急傾斜地崩壊対策事業の一環として, 昭和 44 年から平成 9 年までの 29 年間にわたり全国で発 生した土砂災害のデータを集積している. 本研究におい ては，このうち資料集 ${ }^{50}$ のして公開されている昭和 50 年〜 57 年の 8 年分のデータを用いて斜面崩壊に起因す る道路不通のリスクを評価する，具体的には，斜面の形 状・高さ等，特別に地質調査を必要としない情報を用い て斜面の下端から崩土先端までの水平距離である崩土到 達距離を確率的に求めることにする.

筆者らは，これまでにもニューラルネットワークを用 いて崩土到達距離を予測するための研究を行っている しかし, 過去の研究では崩土到達距離予測值と実測值の 差が数\%以内となる精度を要求したため, 満足できる結 果が得られずニューラルネットワークの限界を感じ研究 を打ち切りとした.

しかし，崩土到達距離の実測值を理論上の到達距離と ばらつきを合計した值と考えると，過去の研究とは別の 評価ができる，すなわち，理論上の崩土到達距離は予測 值と実測值の差である残差を加えて評価できると考え， その残差の分布が正規分布等統計的に妥当な分布特性を 有することを確認することで，崩土到達距離を確率的に 評価できる，ここでは，崩土到達距離の予測にはニュ ーラルネットワーク (バックプロパゲーション法(BP 法)）を用いる。 そして，残差の分布を正規分布にあては めることで，残差を理論值からのばらつきと考えること の妥当性を示す.

このような予測問題では普通，重回帰分析や数量化理

表-2 斜面崩壊データ

\begin{tabular}{|c|cc|c|cc|}
\hline 府県名 & \multicolumn{2}{|c|}{ データ数 } & 府県名 & \multicolumn{2}{|c|}{ データ数 } \\
\hline 京都 & 19 & $(17)$ & 鳥取 & 11 & $(11)$ \\
\hline 大阪 & 15 & $(14)$ & 島根 & 74 & $(66)$ \\
\hline 兵庫 & 90 & $(76)$ & 岡山 & 67 & $(66)$ \\
\hline 奈良 & 29 & $(12)$ & 広島 & 121 & $(80)$ \\
\hline 三重 & 26 & $(26)$ & 山口 & 152 & $(140)$ \\
\hline 滋賀 & 4 & $(4)$ & & & \\
\hline 和歌山 & 17 & $(17)$ & 合計 & 625 & $(529)$ \\
\hline
\end{tabular}


論 I類の方法が用いられることが多い，しかし，説明変 数として使用できるのが重回帰分析では量的データのみ に，また数量化理論 I 類ではカテゴリ化データのタに限 定されるのに対して BP 法では両者の混在が許される点 で都合がよい。

崩土到達距離に関係する説明変数として, 表-1 の 13 項目を考える．表中で着色を施した項目が量的データで, その他はすべてカテゴリ化データである．また，13 番

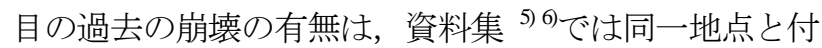
近に分けて記録していたものを合算している.

対象を近畿地方及び中国地方に限定すると表-2 の通り 625 件の斜面崩壊データがある. しかし，一部のデータ が欠損しているものも少なくなく，そのようなデータを 除くと表-2の括弧内に示寸通り529件となった.

\section{(2) データのフィルタリング}

データ群の中には均一性を乱すデータが存在し，予測 精度の低下を招く原因となる。 そこで，分析に先立って， 特異なデータを見つけ出し取り除くフィルタリングの操 作が必要となる. 通常, 特異なデータを見つけ出すため に，基本統計量を調べ，またヒストグラムや散布図を作 成する方法が考えられる。しかし，データ量・項目が多 いときには大変な作業となる.

そこで，本研究ではサモンマップ 8)を用いて特異デー タの抽出を行った，サモンマップは多次元空間内のデー 夕を 2 次元平面で表現する図化手法である. 平面上の座 標值は，データ同士の距離関係が多次元空間上での距離 関係とほぼ同等となるように決められる.

図-1 がサモンマップである. 図中に示したラベルは県 名の 1 字, 年度および連番で構成されている.この図の 縦横軸に示された数值はデータ点の座標值を表すが，サ モンマップでは視覚的にデータ点の塊をとらえることで

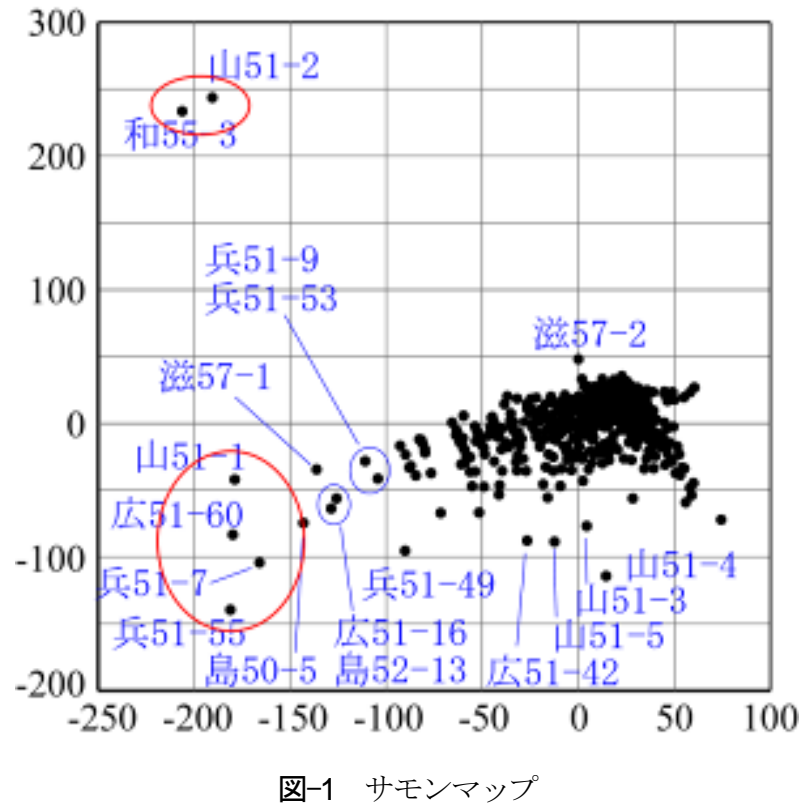

分析を行うため, この数值自体は意味を持たない.

図-1 の赤丸で囲んだデータが他から離れており，特異 なデータであることが分かる，そこで，これらのデータ が他のものとどのような点で異なっているのかを調心゙る。 特異と思われるデータと他のデータ群と比較した結果, 斜面の高さおよび崩土到達距離が極端に大きいことが分 かった，そこで，斜面の高さ一崩土到達距離の散布図を 作成すると図-2 のようになる. 2 つ図に示したデータ ラベルを比較すると，サモンマップで特異と思われた点 は散布図でもやはり特異と感じられる。

これらのデータが外れ值といえるかどうかを調べるた めに，崩土の到達距離及び斜面の高さについてスミル， フ・グラブス検定 9)を行った. 検定の結果 33 件が外れ 值として検出された．検定により検出されたデータは図 -1, 図-2で抽出されたものと一致している.これらの分 析結果をもとに，この 33 件を除外して，以後の分析に 用いるデータは496件とした。

\section{(3) BP 法による予測システムの構築}

前述の 496 件のデータを学習に用いるデータ 466 件と 予測システムの検証に用いるデータ 30 件の 2 つのグル ープに分ける.

予測に用いた BP 法のニューラルネットワークは，入 力層, 中間層および出力層の 3 層構造で, 入力層の二ュ 一ロン数は 13 個，出力層では 1 個とした.

中間層のニューロン数を $n$ としたとき，学習により決 定すべき結合重みの総数 $N_{w}$ は $(13+1) \times n+(n+1) \times 1$ とな るが，これと学習データ数 $\left.N_{d}=466\right)$ の比 $N_{d} / N_{w}$ をできる だけ大きくすることが学習上望ましいとされている，本 研究では $N_{d} N_{w}>2$ を満足寸ることを条件として,$n$ を変 化させて試算した結果 $n=10$ を採用することとした．こ のとき $N_{d} N_{w}$ は 3.1 となる. 学習回数は試験的に実施し

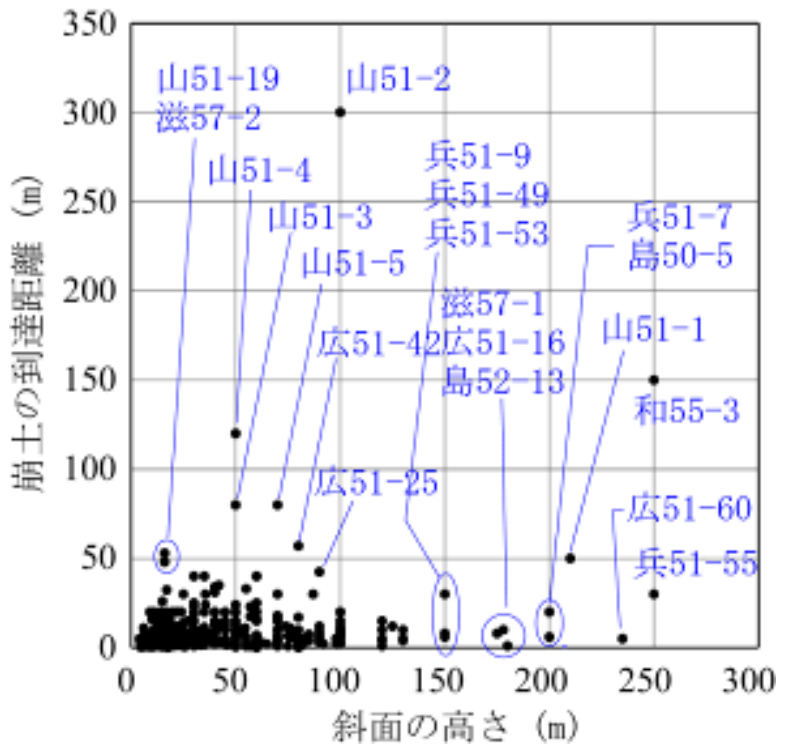

図-2 散布図 


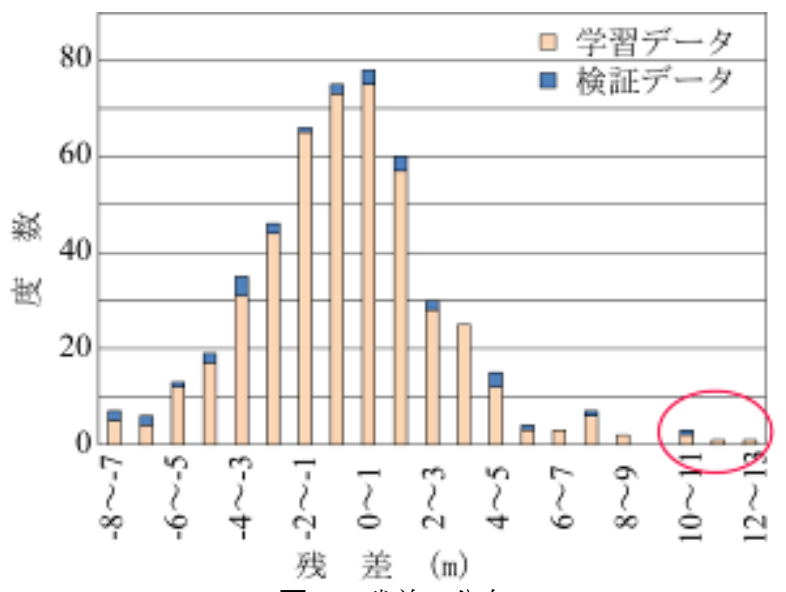

図-3 残差の分布

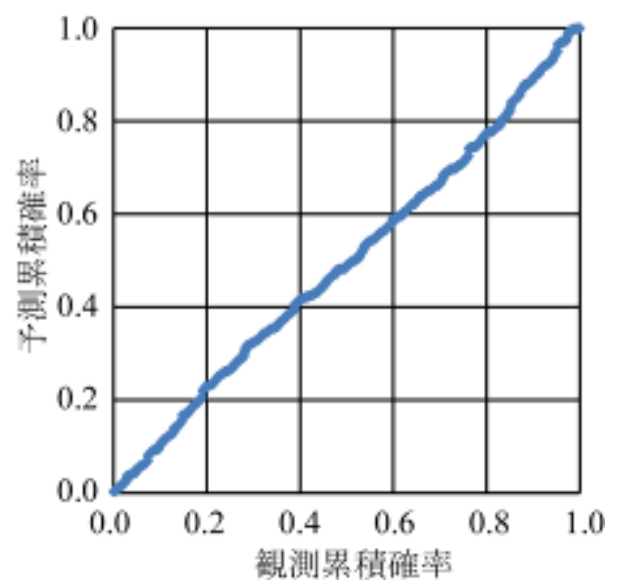

図-4＼cjkstart正規確率プロット（正規P-P プロット）

表-3 予測システムを用いた崩土到達距離の予測值とその超過確率

\begin{tabular}{|l|c|c|c|c|c|c|}
\hline データ名 & 実測值 $(\mathrm{m})$ & $\begin{array}{c}\text { 予測值 } \\
L_{m}(\mathrm{~m})\end{array}$ & $\begin{array}{c}A=L_{m}+\overline{\Delta L}_{m} \\
(\mathrm{~m})\end{array}$ & $\begin{array}{c}A+\sigma_{L} \\
(\mathrm{~m})\end{array}$ & $\begin{array}{c}A+2 \sigma_{L} \\
(\mathrm{~m})\end{array}$ & $\begin{array}{c}A+3 \sigma_{L} \\
(\mathrm{~m})\end{array}$ \\
\hline 岡山 51-13 & 10.0 & 14.96 & 15.12 & 18.08 & 21.03 & 23.99 \\
\hline 島根 52-35 & 2.5 & 0.31 & 0.47 & 3.42 & 6.38 & 9.34 \\
\hline 大阪 51-11 & 6.0 & 5.23 & 5.39 & 8.34 & 11.30 & 14.25 \\
\hline 兵庫51-12 & 5.0 & 4.29 & 4.44 & 7.40 & 10.35 & 13.31 \\
\hline 三重57-11 & 5.0 & 8.52 & 8.69 & 11.64 & 14.60 & 17.55 \\
\hline 生起確率 & & $55.8 \%$ & $89.5 \%$ & $96.8 \%$ & $99.1 \%$ \\
\hline 超過確率 & & $44.2 \%$ & $10.5 \%$ & $3.2 \%$ & $0.9 \%$ \\
\hline
\end{tabular}

た学習結果を参考にして 5,000 回とした.

図-3 は予測システムによる学習データの残差 $\left(\Delta L_{m}=\right.$ 予 測值一実測值)のヒストグラムである。また, 図-3 の赤 丸内のデータ(5 件)を外机值と考えて削除し, 正規確率 プロットを行うと図-4 のようになる．図-3，図-4 から残 差は正規分布に従っていると仮定して，コルモゴロフ・ スミルノフ検定を行うと有意確率 $\mathrm{P}$ は 0.0697 となり仮定 は採択された。

残差の平均值 $\overline{\Delta L}_{m}$ は $0.16 \mathrm{~m}$, 標準偏差 $\sigma_{\mathrm{L}}$ は $2.96 \mathrm{~m}$ と なった．また，検証データで残差 $\Delta L_{m}$ が $-3 \sigma_{\mathrm{L}}$ を下回る ものは 30 件中 0 件， $3 \sigma_{\mathrm{L}}$ を上回るものは 2 件であった.

表-3には検証用データの一部について予測システムを 用いた崩土到達距離の予測值と, 崩土がある距離を超え る確率(超過確率)を正規分布に従って求めた結果も併せ て示している.この結果を用いれば，斜面崩壊で道路が 完全に不通となる場合，あるいは片側は通行可能である 場合のリスクを確率的に評価することができる.

\section{3. $\mathrm{BCP}$ への適用事例}

（1）適用地域

大阪府北摂地域の中山間地に位置寸る大阪府豊能郡豊 能町を事例として，崩土による道路閉塞が BCP の実施 に及ぼす影響を調べる. 同町で検討している BCP とし ては, 国道の広域緊急交通路や府道などの地域緊急交通 路である道路ネットワークに支障が生じない，もしくは，
支障が生じたとしても短期間で通行が確保されることを 前提としている。 これは，道路ネットワークの管理が， ほとんどの場合複数の管理者に分散して行われ，情報も 限られており，1 管理者だけではネットワーク全体にわ たる被害を想定することが困難なためである.

そこで，豊能町及びその周辺の北摂地域において，緊 急交通路に面した急傾斜地崩壊危険箇所の斜面に本研究 の手法を適用することとした.

\section{（2）急傾斜地における崩土到達距離の予測}

大阪府豊能郡豊能町において, 急傾斜地崩壊危険箇所 は，全部で 85 箇所あるが，このうち広域緊急交通路及 び地域緊急交通路に面している斜面は約 20 箇所である. ここでは, 豊能町役場本庁周辺に的を絞り, 図-5 に赤色 で示した広域緊急交通路の国道付近で 2 箇所, 青色で示 した地域緊急交通路の府道付近で 1 箇所の計 3 箇所の斜 面について解析を行った. 3 つの斜面の崩土到達距離は 表4のように求まった．なお，BP 法による予測システ ムは検証用データも加えて 496 件の全データを学習して 再構成している.

崩土到達距離を平均值 $+3 \sigma_{\mathrm{L}}$ と考えれば，箇所(1)び (3)では緊急交通路が完全に崩土により閉塞することが分 かった．また，箇所(2)では、道路まで到達することはな いものの, 河川が崩土により完全に閉塞してしまい, 道 路や周辺家屋への二次災害が懸念される結果となった. 


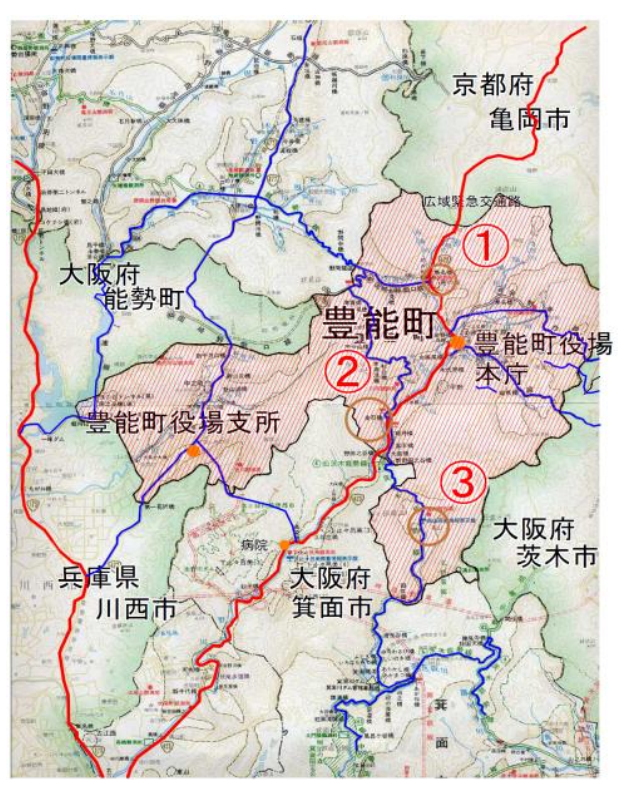

図-5 大阪府北摂地域の急傾斜地危険箇所

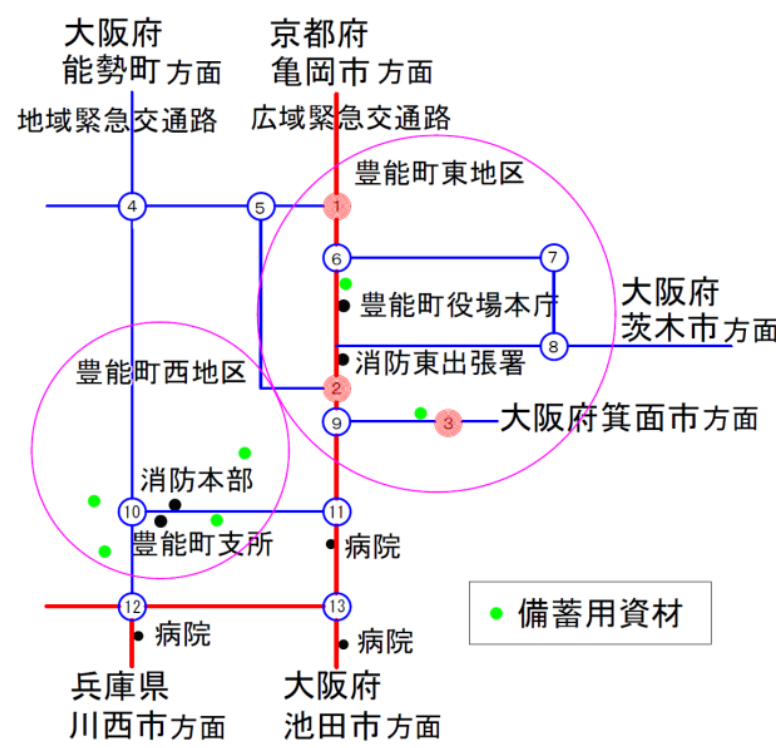

図-6 大阪府北摂地域の道路ネットワーク

(3) $\mathrm{BCP} \sim の$ 適用

大阪府北摂地域の道路ネットワークを模式的に表すと 図-6のようになる。この広域緊急交通路ネットワークで 箇所(1)及び(2)が閉塞などにより通行不可となると，初動 業務（フェーズ 1）の職員参集さえできない可能性があ る. そのため, その後に行うフェーズ 2 の救助・救急活 動や電力・通信・上水・下水等のライフラインの復旧, 近隣市からの応援物資輸送などに大きく影響を及ぼす可 能性がある.

よって，このような事態の備えとして，道路閉塞等の 復旧に要する時間をある程度把握しておく必要がある.

図 - 7 は各箇所の実際の斜面の様子を示たものであり, 各断面図に示した赤線が斜面の崩壊線を示している. 崩 壊線は斜面下端より平均值 $+3 \sigma_{\mathrm{L}}$ の位置を端部とし，崩 壊線の上側と下側の土量が等しくなるような勾配を設定
表-4 急傾斜地危険箇所における崩土到達距離

予測と応急復旧に要する時間

\begin{tabular}{|c|c|c|c|c|}
\hline \multicolumn{2}{|l|}{ 解析結果 } & 箇所(1) & 箇所(2) & 箇所(3) \\
\hline 予測值 $L_{m}$ & (m) & 7.69 & 19.60 & 1.66 \\
\hline$A=L_{m}+\overline{\Delta L}_{m}$ & (m) & 7.85 & 19.76 & 1.82 \\
\hline$A+\sigma_{L}$ & (m) & 10.81 & 22.72 & 4.78 \\
\hline$A+2 \sigma_{L}$ & (m) & 13.77 & 25.68 & 7.74 \\
\hline $\mathrm{B}=A+3 \sigma_{L}$ & (m) & 16.73 & 28.64 & 10.70 \\
\hline $\begin{array}{l}\text { 斜面下端から道 } \\
\text { 路までの距離 C }\end{array}$ & (m) & 6.73 & 30.0 & 0.0 \\
\hline \multicolumn{2}{|c|}{ 応急復旧土量面積 D $\left(\mathrm{m}^{2}\right)$} & 29.1 & 38.0 & 41.6 \\
\hline \multicolumn{2}{|c|}{ 崩壊道路延長 (m) } & 180.0 & 450.0 & 100.0 \\
\hline \multicolumn{2}{|c|}{ 崩壊土量 $\left(\mathrm{m}^{3}\right)$} & 5242.5 & 17100.0 & 4155.0 \\
\hline \multicolumn{2}{|c|}{ 斜面崩壊後の状況 } & 道路閉塞 & 河川閉塞 & 道路閉塞 \\
\hline \multicolumn{2}{|c|}{ 応急復旧時間（日） } & $8.0($ 片側) & 27.0 & 6.0 (片側) \\
\hline
\end{tabular}

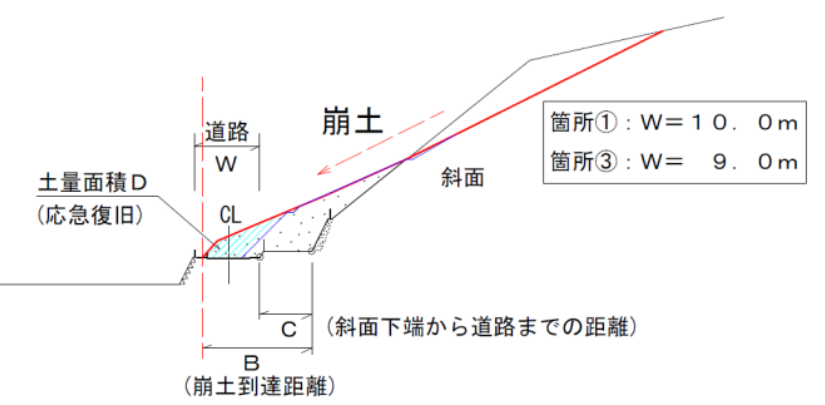

(1) 箇所(1), (3)

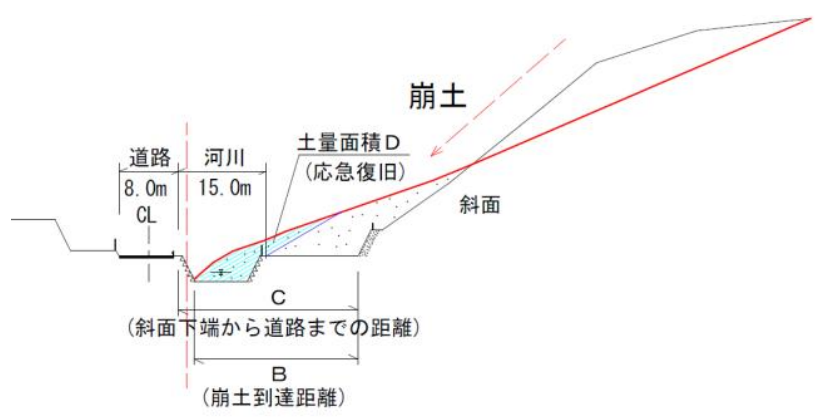

(2) 箇所(2)

図-7 崩壊断面図

して仮定したものである.

応急復旧のため 1 車線の通行を確保するものとして, 廃土断面を図 - 7 の水色部分のように考えて土量面積 D を算出した。ささらに土砂災害危険箇所マップを参考に崩 壊道路延長も計測し, 崩壊土量と応急復旧時間を算出し た. その際, 中山間地域での作業で施工ヤードもないた め，復旧作業が両側から実施できるものとした．ただし， 二次災害防止のため夜間作業は考慮していない. また, この復旧作業も建設機材等の調達が可能であることを前 提条件としている.

表 - 4 の忘急復旧時間によると，図-6 の豊能町役場本 庁周辺の箇所(1)，(2)においては，片側通行が可能となる までに 8 日間を要し，その間は孤立してしまう可能性が ある．物資輸送路として,大阪府茨木市側(図-6 の(7)(8)の 
地域緊急交通路からの進入も考えられるが，豊能町内だ けでも計 6 箇所の急傾斜地危険箇所があるうえ，他市も 同様の地形であることから同様に崩土により閉塞してい る可能性がある.

したがって，箇所(1)または(2)のどちらか 1箇所につい ては崩壊防止を目的としたハード対策または迂回路の確 保などの予防対策が必要である。これは，発災直後に行 政が行うべき最初の重要業務である「住民生活の正常 化」，「避難生活の安定化」ためにも必要な対策である。

また，図-6に示すとおり備蓄用資材の保管箇所として は，地域防災計画では西地区の豊能町支所を中心とした 各小学校等が指定されているが，東地区の本庁周辺には あまり備蓄用資材が確保されていない状況である。箇所 (1)，(2)の閉塞によって東地区では物資の不足に陥る可能 性もあり，備蓄計画を見直す必要がある.

このようにリスクを顕在化していくことで，従来の防 災計画では災害発生後の危機管理対応が十分できず復 旧・復興の遅れに繋がることが明らかとなった．想定以 上の事態が発生した場合はとくに深刻な事態に陥ること になるため，事前に様々な種類・規模の災害が発生した 場合を想定した BCPの構築が必要性である.

\section{4. あとがき}

本論文では道路ネットワークが有するリスクのうち， 自然斜面・切土斜面に着目し, 斜面の崩壊により道路交 通が阻害されるリスクを確率的に評価する方法を提案し た. そして，その提案手法を大阪府北摂地域の中山間地 に位置する大阪府豊能郡豊能町内の道路ネットワークに 適用して，斜面崩壊に伴う道路閉鎖等による危機的状況 の把握並びに復旧上の課題を指摘し，被災後の対応を効 果的に実施するための BCP策定の重要性を示した.

今後の展開として, 地域内での対象斜面を増やして, 急傾斜地に面する緊急交通路網全てに適用寸ること，ま た斜面崩壊リスクに止まらず橋梁やトンネルなど様々な リスクについても検討することを考えている. さらに, 近年過去に例のない想定を越える災害が多数発生してお り，例えば中山間地域では山体崩壊のような想定以上の
災害についても視野にいれていく必要がある，想定外災 害に適切に対応するためには, リスクを限定的なものと せず可能な限り大規模かつ広域にわたる被害に対して対 応する必要がある. 今後は, そのような想定外の事態に 対しても解析し, 得られた結果を BCP に基づく改修計 画の立案, 復旧体制の整備, 諸資材の備蓄計画などに反 映し，地方行政版の実践的 BCP の策定に繋げたいと考 えている.

\section{謝辞}

本研究の実施にあたり湖山構造研究会の会員諸兄には データ入力に協力いただき，また議論に参加し有意義な 意見をいただいた. ここに関係各位に深く感謝の意を述 ベるものである.

\section{参考文献}

1) 丸谷浩明 : 事業継続計画の意義と経済効果〜平常時に評 価される実践マネジメントへ，ぎょうせい，2008.5.

2) 総務省ホームページ : http://www.soumu.go.jp/.

3) 特定非営利活動事業継続推進機構 : http://www.bcao.org/index.html.

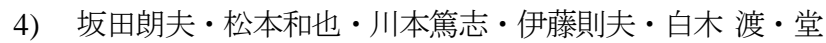
垣正博: 地方公共団体における業務継続計画策定ガイド の提案, 安全問題研究論文集, 土木学会, Vol.5, pp. 19-24, 2010.11.

5）建設省河川局砂防部傾斜地保全課，建設省土木研究所砂 防部急傾斜地崩壊研究室：がけ崩れ災害実態について (昭和 50年 52 年) (資料集), 1978.3.

6）建設省河川局砂防部傾斜地保全課，建設省土木研究所急 傾斜地崩壊研究室 : がけ崩れ災害実態について (昭和 53 年 $\sim 57$ 年), 1983.8.

7) 伊藤則夫 ・白木 渡 -今井慈朗・井面仁志・石川浩 : 自己 組織化特微マップを用いた斜面崩壊予測システムの高精 度化に関する研究, 第 15 回ファジイシステムシンポジウム 講演論文集,1999.6.

8) T.コホーネン著,徳高平蔵ら監修 : 自己組織化マップ改訂 版,シュプリンガー・ジャパン,2005.6.

9）社会情報サービス統計調查研究室 : http://software.ssri.co.jp/statweb2/sample/example_17.html.

(2011.7.22 受付)

\title{
A STUDY ON PREPARING THE BCP FOR LOCAL ADMINISTRATION COSIDERING SUBSISTED RISK ANALYSIS OF ROAD NETWORK
}

\author{
Akio SAKATA, Norio ITO, Atsushi KAWAMOTO,Wataru SHIRAKI
}

For road networks in mountain site which are very important infrastructures for rescue and support operations in disaster, a study on preparing the BCP for local administrations at less favored area considering subsisted risk analysis is performed. As a risk the stop of road networks caused by collapse of natural slop or cut slop is considered. The effects of the stop of road networks are analyzed and the important of preparing the BCP is demonstrated. 